\title{
Criminal Liability for Illegal Production and Distribution of Pornographic Materials and Objects: Theory and Practice
}

\author{
Aleksey A. Shirshov \\ Far Eastern Federal University; Email: brahma@bk.ru
}

Doi:10.5901/mjss.2015.v6n5s3p126

\begin{abstract}
The article is devoted to problems in law enforcement practice in the qualification of crimes related to illicit trafficking of pornographic materials in the Russian Federation. The author analyzes the norms of the Russian criminal legislation which provides for the punishment for illegal trafficking of pornographic materials, norms of international law, being blanket against the norms of the national legislation, the practice of criminal law for illegal trafficking of pornographic materials. The article discusses the main components of crime which provide for the responsibility for illegal trafficking of pornographic materials, as containing images of minors, and also not using of such; the analysis of the different degree of public danger of crimes related to illegal trafficking of pornographic materials, challenged is the legality and validity of the existing law enforcement practice, actually completely criminalizing the trade of pornographic materials in Russia; the correctness and completeness of the components of crimes in the sentences of the courts are investigated. Particular importance is paid to the study of both objective and subjective grounds of responsibility for the offences in criminal law of Russia and the problems associated with significant gaps in the legislative regulation of the trade of pornographic materials in Russia. The author concludes that namely because of the existence of gaps in the regulation the current law enforcement practice often contradicts with the basic principles of criminal law and violates rights and freedoms of convicted persons under specified articles.
\end{abstract}

Keywords: criminal liability; pornography; pornographic materials; child pornography.

\section{Introduction}

In its essence, the problem of criminal responsibility for trafficking of pornographic materials very clear, even hypertrophied, shows the overall complexity and contradictions faced by the law enforcement agencies and the courts, implementing in practice the Criminal code of Russia. One year left before the 20-year anniversary since the adoption in 1996 of the Criminal Code of the Russian Federation. However, it should be noted that in its original complete form prior to the anniversary the criminal law did not survive: perhaps of all legal acts namely the criminal code has undergone the most significant and large-scale changes.

It would seem that such a long period of existence of the criminal law was to allow the law enforcer to identify "weak spots" of the Criminal Code, and the legislator - to systematically develop the system of criminal-legal means and methods of protection of interests of personality, society and state, to develop and adopt a system of laws and regulations, to ensure the correct and uniform interpretation and application of the criminal law. Alas, last year's did not show the availability of a balanced and thoughtful approach to the formation of criminal law policy of the Russian state. Legislator weakly listens to the aspirations of law enforcers, regularly conducting the campaign to combat certain types of crime, often ad hoc in response to specific events. Today we are forced to acknowledge the loss by the criminal law of the integrity and systemacity, frequent and unjustified expansion of the criminal legal repression, the lack of conceptualization and inconsistency throughout the modern criminal and criminal-legal policy of Russia.

Unfortunately, the domestic legal system failed to overcome the "baby" problems associated with unwillingness of law enforcer to follow not only the spirit but also the letter of the law. In the opinion of the author, in this sense, the situation surrounding the norms of the criminal law governing penalties for trafficking of pornographic materials and objects are particularly revealing and witnesses a violation of the basic principles underlying the criminal law regulation: such as the principle of legality and the principle of guilt.

\section{Literature Review}

Considered this article issues attracted the few attention of Russian researchers. The bulk of the work, devoted to the distribution of pornography (including via the Internet) is of a journalistic nature. There are very little serious legal 
researches on the problems of criminal liability for trafficking of pornographic materials in Russia. Some of the issues related to trafficking of pornographic materials and objects were reviewed at the dissertation level by the M. V. Gusarova. In addition, it should be noted that virtually any textbook on the Special part of criminal law for law students contain in itself an analysis of those norms of the Criminal Code. G. A. Esakov, A. I. Chuchaev, V. P. Konyakhin, E. V. Blagov, and others wrote about it. However, this analysis tends to be non-critical in nature. Therefore, these issues require further research and development.

\section{Methods and Materials}

In addition, the author has studied 200 sentences for specified category handed down by various courts of territorial entities of the Russian Federation.

Methodological base of research is a result of both general scientific methods of cognition (analysis, synthesis, generalization, induction, deduction) and also from private scientific research methods (formal-legal, historical-legal, systemic-structural, comparative-legal, statistical, sociological).

\section{Results and Discussion}

First of all, the fact of necessity of criminalization of trafficking of pornographic materials and materials causes doubts. Let's try to determine the attitude of the Russian legislation towards it. First of all, it is necessary to figure out which social relations threaten criminal assaults under articles 242, 2421 and 2422 of the Russian Criminal Code providing for criminal liability for trafficking and manufacturing of pornographic objects and materials. The standards are placed in Chapter 25 of the Code, having the title "Crimes against public health and public morality". Accordingly, a generic object of named criminal law norms should serve the public health and public morals.

At first, it is necessary to stay on article 242 of the Russian Criminal Code, which establishes liability for the illegal production, transfer across the State border of the Russian Federation for the purposes of distribution, public demonstration or advertising or distribution, public demonstration or advertising of pornographic materials or objects (the first part of article 242 of the Criminal Code of the Russian Federation in edition of the Federal law dated 29.02.2012 No. 14-FL). Analysis of this norm leads to the conclusion that the subject of the article 242 is usual pornographic materials and objects not connected with the use of minors or their images.

Unity of views on the harm that is caused by a "normal" pornography to adults was not developed by special literature. However, specialists estimated the demonstration of violence in pornographic materials in obviously negative way. Established in 1985 by U.S. A. President Ronald Reagan, "the Commission of the Attorney General" (Attorney General's Commission). to the question about the effect on society of pornography, noted the following: "The clinical data and other evidence supports the conclusion that propaganda of sexually violent materials causes the increase of violence against women" (Attorney General's Commission, 1986. Page. 39).

However, the European Parliament rejected an offer to ban pornography. This idea was put forward as one of the necessary steps to combat discrimination against women, which were first announced in December 2012 in the report of the Committee on women's rights and gender equality (Neal, 2013). Many critics agreed with the assigned problems still existing in Europe gender inequality, however, measures to eliminate the problems seemed questionable: for example, according to them all undesirable images of women in media and popular culture should be prohibited, until the princesses in storybooks, always in need of rescue (Arbatova, 2013).

This shows the demand for pornographic materials. Of course, this need, as any other, is socially determined. One may speculate that it is due to moral and ethical level of development of society and to recall that the attitude to pornography was changing from a complete denial to the actual recognition. It is important to understand that the rejection of tabualizing of questions of sex should lead to a definite conclusion - for an adult pornography represents private interest. Obviously, the European Parliament came out of it. Completely banning the trade of pornographic materials, the legislator invades very intimate issues of privacy, that is, in those questions that in themselves should not be a subject of legislative regulation, because are hidden from society by tightly closed doors of bedrooms: therefore intimate life and called intimate. Therefore, to say that from the distribution of pornography is suffering morality, is not correct: the fact is that there is no universal approaches to determining what is moral or immoral. Our concepts of morality change with the development of society.

On the other hand, absolutely uncontrolled distribution of objects and materials of pornographic content is also inadmissible. Researchers almost unanimously agree that pornography brings undoubted harm to the normal psychological development of adolescents, (Cline, 2011; Coetzee, 2013), provokes them to commit rape sessions 
(Kheswa and Notole, 2014). Moreover, the authors are unanimous about the extremely negative impact of pornography on children (Coetzee, 2013).

It should be noted that the above arguments are less applicable to Russian legal reality. Speaking about the trafficking of pornographic objects and materials in Russia, it should be remembered that direct rules governing the trade does not exist.

The situation with the legal regulation of the above subject is ambiguous. Drawing an analogy with the well-known fact of Larry Flynt it should be noted that the current Russian Constitution in clause 4, article 29 establishes the right to freely seek, receive, transmit, produce and distribute information by any legal way. Any information can be classified as the information of a pornographic nature, except to that which trade is not expressly prohibited by the legislator.

Russian criminal legislation contains three rules providing for the responsibility for the circulation of pornographic materials. Moreover, the essence of these rules is of fundamental differences.

So, in part 1 of article 242 of the Russian Criminal Code (illegal production and distribution of pornographic materials or objects) the legislator describes two component elements of a crime: the first provides for liability for illegal production and (or) traffic across the State border of the Russian Federation for the purposes of distribution, public demonstration or advertising of pornographic materials or objects; the second for illegal distribution, public demonstration or advertising of pornographic materials or objects.

Part 2 of article 242 provides for liability for the distribution, public demonstration or advertising of pornographic materials or objects among minors or minor involvement in the trade of pornography, committed by a person under the age of eighteen.

Analyzing the text of the above rules, it is possible to make an unambiguous conclusion that the criminal law does not contain a complete prohibition of trafficking in pornographic materials on the territory of the Russian Federation. This is evidenced by the term "illegal", which characterizes the legislator's actions, forming the objective party of this crime.

Thus, the provisions of article 242 of the Criminal Code is blanket, that is, for its application it requires special norms regulating the trafficking of pornographic materials and objects. Let's draw attention to the fact that the Russian Constitution contains a provision on the direct effect of norms of international law. Universally recognized principles and norms of international law and international treaties of the Russian Federation are a component part of its legal system. If an international treaty of the Russian Federation establishes other rules, than provided by law, the rules of the international treaty are used (part 4 of article 15 of the Russian Constitution taking into account amendments made by the laws of the Russian Federation subject to the laws on the amendments to the Constitution of the Russian Federation of 30.12.2008 № 6-FKL, of 30.12.2008 N 7-FKL, of 05.02.2014 N 2-FKL, of 21.07.2014 N 11-FKL).

In 1910, in Paris, 15 countries have signed an International agreement to combat the spread of pornographic publications. Among its participants was Russia. States have committed themselves to create special national authorities to centralize all information on such crimes, to promote international investigation and suppression, to inform each other about laws, the sentences imposed by the courts on such criminal cases. In the agreement, however, was not even the list of illegal acts, not even to mention the other issues of substantive criminal law. September 12, 1923 in Geneva was adopted effective from today, international Convention on the suppression of pornographic publications and their trade (Convention for the Suppression of the Circulation of and Traffic in Obscene Publications), to which 8 July 1935 joined the USSR. The Convention provides for the suppression of unlawful pornographic publications and their trade. In 1927 in Warsaw hosted the first international conference for unification of criminal law, where together with crimes against international law, such as piracy, falsification of metallic money and government securities, trading in slaves, women and children, illegal drug trafficking, the responsibility for which is provided by international conventions, has been referred also pornography.

In fact, in Russia there are no other rules, in addition to regulating the trafficking of pornographic materials and materials. The interpretation of the term "illegal" used in paragraph 1 of article 242 of the Criminal Code raises serious difficulties. Does all of the above mean that the circulation of pornographic materials is absolutely forbidden in Russia? A definite answer to this question may provide an analysis of the text of the criminal law. The text of the law is unambiguous and does not admit of a different interpretation. Part 1 of article 242 of the Criminal Code does not contain absolute prohibition on the trade of mentioned objects.

In contrast, analysis of the text of the law shows that the absolute prohibition refers to the distribution, public demonstration or advertising of pornographic materials or objects among minors, as well as their involvement in the trafficking of pornography.

Even more clearly illustrates the absence of a complete ban on the trade of pornographic materials comparative analysis of the art. 242 and $242^{1}$ of the Criminal code of Russia. Article $242^{1}$ completely prohibits on the territory of the Russian Federation production, acquisition, storage and (or) moving across the State border of the Russian Federation 
for the purposes of distribution, public demonstration or advertising or distribution, public demonstration or advertising of materials or objects with pornographic images of minors. Let's pay attention to the fact that in the drafting of article $242^{1}$ the legislator, in contrast to article 242 of the Russian Criminal Code, does not use the term "illegal", which allows to make a conclusion about the presence of the absolute prohibition of pornographic material of a corresponding nature.

Article $242^{2}$ also contains two absolute prohibitions: first, on photo, film or video of minors for the purpose of production and / or distribution of pornographic materials or objects; secondly, the involvement of a minor as a performer to participate in a spectacular event of a pornographic nature.

Thus, in the Russian Federation is prohibited: 1) illegal trade of "normal" (not containing images of minors) pornographic materials among adults; 2) any trade of any pornographic material to minors; 3 ) any trade and production of pornographic materials involving minors.

Taking in 1996, the Criminal Code, the legislator proceeded from the assumption on the limited admissibility of legal circulation of pornography, as it is already in practice in many countries of the world.

The answer to the question about what aspects necessary for the correct application of criminal law norms should be developed by the legal act regulating the circulation of pornography and pornographic materials in Russia is also quite obvious. First, since the legislator abandoned the use of descriptive principle in the rules on criminal liability for trade of pornographic materials, it is necessary at the legislative level to determine what is the subject of the offences of specified group, in other words, what should be classified as pornography. Secondly, as in part 1 of article 242 of the Criminal Code we are talking about illegal trade of pornographic materials, normative-legal act must establish the boundaries of the legal circulation of such materials.

Attempts to create a legal act, in which would have been given definitions of "pornography" "pornographic material", "erotica", "erotic work", would be possible to find the criteria for their separation from each other, would be stipulated cases where the trade of pornographic materials is legal in Russia over the past decade have been made repeatedly, but were of no results. In 1997, the State Duma has adopted the law "On strengthening the control over the trade of products of a pornographic nature", which was rejected by President B. N. Yeltsin. The last serious attempt of the legislative initiative was taken by the deputies of the state Duma in 2005, when was presented the project of Federal law on introducing amendments to article 242 of the Criminal Code of Russia, which suggested adding the following note: "Materials or objects print publications, images, computer programs, films, video and sound recordings, broadcasts and other materials and items, the main content of which is roughly naturalistic detailed image of the anatomical and (or) physiological details of sexual relations in the form, contrary to accepted in society moral norms that have no artistic or scientific value and aimed at arousing sensual passion are recognized as pornographic." Alas, the reasons why the bill was rejected in 2006 and then in 2008, remained unknown.

It should be noted that the understanding of the criteria defining is what pornography, in the absence of the law, causes difficulties for the staff of the investigative and judicial authorities. So, $73 \%$ of surveyed judges and $88 \%$ of lawyers are unable to answer the question of what is meant by pornography, and made by others judgments had been vague in nature (Poyanskaya, 2007).

In practice, to determine whether an object or material is pornographic, an examination with the participation of art experts, in particular experts in the field of film or video or TV, or the area to which corresponds object or material is taking place. The question of in what degree expert judgments are based on special knowledge, and not on taste evaluations, of course, remains open.

The main conclusion that can be drawn from the formal-legal analysis of the above legal norms is obvious: part 1 of article 242 of the Criminal Code in Russia should not be applied until there is the relevant law governing the trade of pornographic materials and objects. However, court statistics show the opposite. Annually in Russia are registered about two thousand crimes related to illegal trade of pornographic materials and objects. The courts almost do not acquittal in cases of this category.

The author has investigated 200 sentences of the courts from different regions of the Russian Federation made under part 1 of article 242 of the Criminal Code.

Almost all of the studied sentences have fundamental and fatal at the present level of development of the Russian legislation weaknesses relating to the establishment of both objective and subjective side of the crime. Thus, despite its disadvantages, the sentences are accusatory in nature, and since in almost all cases the courts imposed a punishment not related to real deprivation of liberty, or used a special procedure of judicial proceedings the court acts were not appealed in court of higher instance.

None of analyzed sentences do not fully disclose the grounds of the illegality, which characterizes actions that form the objective side of a crime, and proof of which is required for establishing in the actions of the person of signs of component element of the crime provided by part 1 of article 242 of the Criminal Code of Russia. Only in $15 \%$ of the 
studied sentences the courts have referred to the fact of violation by the defendant of the Geneva International Convention for the suppression of pornography publications and trade in 1923 (Convention for the Suppression of the Circulation of and Traffic in Obscene Publications).

It is obvious that unmotivated court's reference to the illegal nature of the actions of the guilty person in court act is invalid. In fact, in the studied sentences, courts have allowed objective imputation, expressly prohibited by applicable law (paragraph 2 of article 5 of the Criminal Code of Russia).

In all studied cases was carried out examinations on the establishment of a pornographic nature of distributed materials. Through research, the experts were guided by special knowledge in the field of science and art. This cannot but raise the question regarding awareness of the social danger of the act of the defendant. If it requires the examination to determine whether an object or material is pornographic, the producer (or distributor), not possessing special knowledge peculiar to the experts, may not be aware of the pornographic nature of the target of crime. In fact, the decision of a question on presence or absence in actions of the person of the offence is given at the mercy of the experts. However, none of the sentences did not contain an indication of the fact that the pornographic nature of the subject is obvious to the average person who does not possess special knowledge. The above also suggests that courts use objective imputation in making of studied judicial acts.

\section{Conclusion}

On a deep conviction of the author the norms of part 1 of article 242 of the Russian Criminal Code cannot be applied until the adoption of the relevant law regulating the trade of pornographic materials and objects on the territory of the Russian Federation. This conclusion follows from the comparative formal-legal analysis of current legislation that does not require doctrinal interpretation and is not associated with the resolution of a serious conflict between the criminal law and the norms of other branches.

Especially alarming is the fact that the analyzed sentences that came into force, were not the objects of appeal or cassation appeal (although the author doubts the real possibility of their cancellation). Moreover, sentences in cases of crimes under article 242 of the Criminal Code in Russia courts continue to impose consistently, regularly applying objective imputation.

\section{References}

This research is conducted with the support by the Ministry of Education and Science of The Russian Federation. Public research task 29.763.2014/K

Arbatova, М. (2013).Евросоюз заступился за порнографию. http://arbatovagidepar.livejournal.com/935359.html

Attorney General's Commission (1986). Final Report of the Attorney General's Commission on Pornography. Nashville, Tenn.: Rutledge Hill Press, 1986.

Cline, V.B. (1999) Pornography's Effects on Adults and Children. New York: Morality in Media.

Coetzee, S.A. (2013) Learner Sexual Offenders: Cyber Child Pornography. Mediterranean Journal of Social Sciences. Vol 4, No 11. http://www.mcser.org/journal/index.php/mjss/article/view/1366

Kheswa J.G., \& Notole M. (2014) The Impact of Pornography on Adolescent Males' Sexual Behaviour in the Eastern Cape, South Africa. A Qualitative Study. Mediterranean Journal of Social Sciences. Vol 5, № 20 (2014). http://www.mcser.org/journal/index. $\mathrm{php} / \mathrm{mjss} /$ article/view/4159

Neal, D. (2013). European Parliament rejects pornography ban. The Inquirer. http://www.theinquirer.net/inquirer/news/2254205/ european-parliament-rejects-pornography-ban

Polyanskaya M.P. (2009). Уголовно-правовая охрана общественной нравственности в сфере половой морали. (Master's thesis, Vladivostok, Far Eastern State University). 